\title{
FREQUENCY OF SERUM ANTI-CYSTICERCUS ANTIBODIES IN THE POPULATION OF A RURAL BRAZILIAN COMMUNITY (CÁSSIA DOS COQUEIROS, SP) DETERMINED BY ELISA AND IMMUNOBLOTTING USING Taenia crassiceps ANTIGENS
}

\author{
Lúcia M. BRAgAzZA(1,2), Adelaide J. VAZ(2), Afonso D.C. PASSOS(3), Osvaldo M. TAKAYANAGUI(3), Paulo M. NAKAMURA(4), Noeli M. ESPÍNDOLA(2),
} Alessandra PARDINI(2) \& Ednéia C. BUENO(2)

\begin{abstract}
SUMMARY
Considering the impact of cysticercosis on public health, especially the neurologic form of the disease, neurocysticercosis (NC), we studied the frequency of positivity of anti-Taenia solium cysticercus antibodies in serum samples from 1,863 inhabitants of Cássia dos Coqueiros, SP, a municipal district located $80 \mathrm{~km}$ from Ribeirão Preto, an area considered endemic for cysticercosis. The 1,863 samples were tested by enzyme linked immunosorbent assay (ELISA) using an antigenic extract from Taenia crassiceps vesicular fluid (Tcra). The reactive and inconclusive ELISA samples were tested by immunoblotting. Of the 459 samples submitted to immunoblotting, 40 were strongly immunoreactive to the immunodominant 18 and $14 \mathrm{kD}$ peptides. Considering the use of immunoblotting as confirmatory due to its high specificity, the anti-cysticercus serum prevalence in this population was $2.1 \%$.
\end{abstract}

KEYWORDS: Cysticercosis; Seroprevalence; Immunologic tests.

\section{INTRODUCTION}

Human cysticercosis, caused by the larval form of Taenia solium, represents a heavy burden for public health in developing countries in Latin America, Africa and Asia, where it is more frequently observed ${ }^{27,10}$. Cysticercosis is also considered to be an emerging disease in developed countries that receive immigrants from endemic areas ${ }^{25}$.

The high morbidity and mortality rate of human cysticercosis results from the development of the cysticercus inside the central nervous system which causes neurocysticercosis (NC), the most severe form of infection $^{21}$. According to the Pan American Health Organization, the information available about the epidemiologic situation of the teniasiscysticercosis complex in Latin America is incomplete, partly because of the lack of compulsory notification and because of the difficulty and heterogeneity of the methods for investigation ${ }^{4}$.

The high cost of imaging techniques such as computed tomography and nuclear magnetic resonance limits the use of these valuable diagnostic resources to specialized centers, with no access on the part of the population living in endemic rural areas and with no possibility of their use for population screening ${ }^{14}$.

The difficulties in performing serologic surveys for the investigation of cysticercosis are due in part to the low sensitivity and specificity of immunologic tests ${ }^{20}$. Over the last decade, however, there has been a considerable improvement in the serologic diagnosis of cysticercosis which has permitted the application of immunologic tests to studies of the prevalence of the disease ${ }^{3,5,10,17,22,24,26}$.

Large-scale production of Taenia solium cysticercus antigens is impaired by the clandestine slaughtering of infected swine. The antigen of Taenia crassiceps cysticerci obtained by intraperitoneal inoculation of mice has been used with satisfactory efficiency in immunologic test for the detection of anti- $T$. solium cysticercus antibodies $2,11,15,31,33$. Thus, the objective of the present study was to determine the frequency of anti-cysticercus antibodies in serum samples from the inhabitants of the municipality of Cássia dos Coqueiros, SP, by ELISA and immunoblot using $T$. crassiceps antigens.

\section{MATERIAL AND METHODS}

This study was conducted according to the ethical norms of resolution No. 196/96 of the Health Ministry concerning research on human beings in Brazil ${ }^{16}$ and was approved by the Research Ethics Committee of the Faculty of Pharmaceutical Sciences of the University of São Paulo (CEP/ FCF/USP).

\section{Participants}

Cássia group: We studied serum samples from 1,863 inhabitants of the municipality of Cássia dos Coqueiros, SP, collected by one of us

Part of the Doctoral thesis of L. M. Bragazza (Faculty of Pharmaceutical Sciences, University of São Paulo, 2001).

(1) Faculty of Pharmaceutical Sciences, Pontifícia Universidade Católica de Campinas, Campinas, SP, Brasil.

(2) Laboratory of Clinical Immunology, Faculty of Pharmaceutical Sciences, University of São Paulo, São Paulo, SP, Brasil.

(3) Faculty of Medicine, University of São Paulo, Ribeirão Preto, SP, Brasil

(4) Adolfo Lutz Institute, São Paulo, SP, Brasil.

Correspondence to: Prof. Dr. Adelaide José Vaz, Fax: 55 -11- 38132197. e- mail: ajvaz@netpoint.com.br 


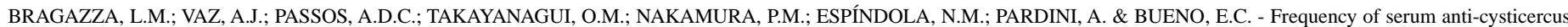
antibodies in the population of a rural Brazilian community (Cássia dos Coqueiros, SP) determined by ELISA and immunoblotting using Taenia crassiceps antigens. Rev. Inst. Med. trop. S. Paulo, 44(1):7-12, 2002.

(ADCP) from October 1987 to May 1990 and stored frozen at $-20{ }^{\circ} \mathrm{C}$ until the time for use.

Cássia dos Coqueiros, SP, is a small, relatively isolated rural municipality located $80 \mathrm{~km}$ from Ribeirão Preto, in the Southeast macroregion of Brazil ${ }^{19}$. According to CHIMELLI et al. ${ }^{4}$, the 1997 prevalence of cysticercosis in Ribeirão Preto was 67 cases/100,000 inhabitants, indicating that the region is endemic for this parasitosis.

The Cássia dos Coqueiros area has been the scene of continuous work with the population. The samples studied were part of an epidemiological investigation of hepatitis B conducted by one of us (ADCP) in 1991. This serum bank contains demographic information $(\mathrm{n}=1,838)$ and information about the sanitary conditions such as source of drinking water $(\mathrm{n}=1,837)$, presence of fecal coliforms in the water source $(n=1,809)$, and area of residence of the participants $(n=1,837)$.

We included in the present study $65.6 \%$ of the total of 2,800 inhabitants of Cássia dos Coqueiros ${ }^{19}$. The study covered $73.6 \%(\mathrm{n}=$ 769) of the persons in the urban area and 60.8\% $(n=1,069)$ of the persons in the rural area.

Evaluation of the variable "source of water for human consumption" showed that $41.7 \%(n=766)$ of the participants used chlorinated water and $58.3 \%(n=1,071)$ used untreated water. Of these 1,071 individuals who used untreated water, $61.0 \%(\mathrm{n}=653)$ used water from collective sources (wells, collective springs, and streams) and $39.0 \%(\mathrm{n}=418)$ used individual sources (individual wells and springs). Among the total number of persons investigated, $48.4 \%(\mathrm{n}=875)$ consumed water contaminated with fecal coliforms and $51.6 \%(\mathrm{n}=934)$ consumed uncontaminated water.

The population studied ranged in age from 2 to 88 years, distributed according to the histogram presented in Fig. 1.

Control Groups: We studied as control groups 114 serum samples distributed as follows: 63 serum samples from individuals with neurocysticercosis confirmed by clinical and laboratory criteria and by imaging exams (Group NC), selected according to the General NC Investigation Protocol of the Hospital of the Faculty of Medicine, University of São Paulo, 28 serum samples from apparently healthy individuals (Group N), and 23 serum samples from individuals who

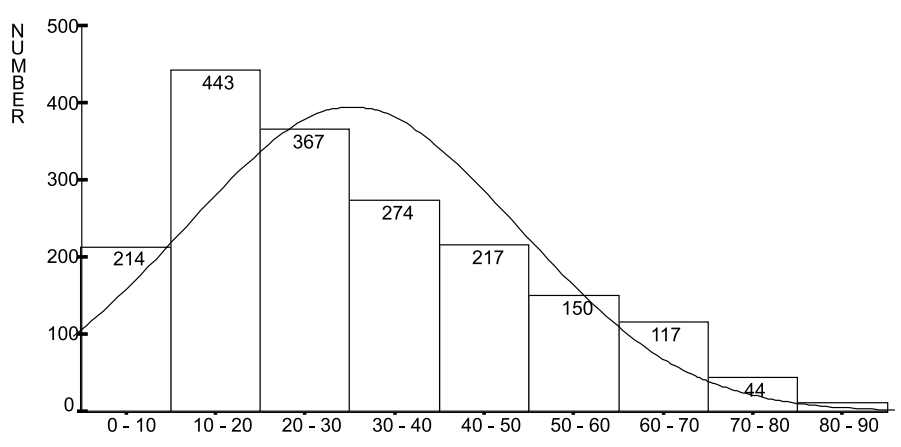

AGE

Fig. 1 - Age distribution of the population of Cássia dos Coqueiros, SP, studied in the present investigation, 1991. (Mean $=30.2 ; \mathrm{SD}=18.52 ; \mathrm{N}=1,838$ ). were positive for other pathologies (Group OP), i.e. toxocariasis $(n=7)$, toxoplasmosis $(n=6)$, Chagas' disease $(n=5)$, and schistosomiasis $(n=$ 5). These samples were from the collection of the Clinical Immunology Laboratory of the Faculty of Pharmaceutical Sciences, USP and were stored frozen at $-20{ }^{\circ} \mathrm{C}$ until the time for the execution of the tests.

Antigenic extract of Taenia crassiceps vesicular fluid (Tcra): The antigen of vesicular fluid of $T$. crassiceps ORF strain cysticerci ${ }^{9}$ was used according to the method of VAZ et al. ${ }^{32}$.

Immunoenzymatic assay (ELISA): The assay was carried out as described by BUENO et al..$^{2}$, with some modifications: the concentration of the antigen extract was $2 \mu \mathrm{g} / \mathrm{mL}$ and the chromogenic substrate was tetramethylbenzidine ( $\mathrm{TMB} / \mathrm{H}_{2} \mathrm{O}_{2}$, Roche Diagnostics Gmbh, Mannheim, Germany).

The result for each sample is reported as reactivity index (RI), calculated by dividing the reading values of the test (absorbance $=$ OD) by the cut-off for the day (mean reading for the normal group plus 3 $\mathrm{SD})$. According to the proposal of the present study, the samples were classified as reactive $(\mathrm{RI} \geq 0.8)$ and non-reactive $(\mathrm{RI}<0.8)$.

Immunoblotting (WB-Tcra): The samples that were reactive by ELISA were submitted to immunoblotting for the analysis of antibody specificity.

The Tcra antigen extract (6 to $12 \mu \mathrm{g} / \mathrm{mm}$ ) was separated by polyacrylamide gel electrophoresis in the presence of dodecyl sulfate (SDS-PAGE) on a gel gradient $(7-20 \%)^{13}$ and transferred electrophoretically to a $0.2 \mu \mathrm{m}$ nitrocellulose membrane (Millipore, Bedford, MA, USA $)^{28}$. The serum samples were diluted $1: 100$ in $1 \%$ skim milk in Phosphate-buffered saline (PBS: $0.01 \mathrm{M} ; \mathrm{pH}=7.2 ; 0.0075 \mathrm{M}, \mathrm{Na}_{2} \mathrm{HPO}_{4}$, $0.025 \mathrm{M} \mathrm{NaH}_{2} \mathrm{PO}_{4}$, and $0.14 \mathrm{M} \mathrm{NaCl}$ ) containing $0.05 \%$ Tween 20 (PBSTween 20). The immunoenzymatic reaction was carried out according to the protocol described by BUENO et $a .^{2}$, except for peptide development which was performed using a chromogenic solution of $\mathrm{H}_{2} \mathrm{O}_{2}$ and 4-chloronaphthol (Sigma Chem.Co). Peptides of 14 and $18 \mathrm{kD}^{2}$ molecular weight were considered to be specific.

Statistical Analysis: Data were tabulated using the SPSS (Statistical Package for Social Sciences) package (version 7.5 for Windows) and analyzed by the chi-square and exact Fisher test, with the level of significance of $\mathrm{p} \leq 0.05$.

\section{RESULTS}

ELISA: The results of ELISA-Tcra for all sera from the control groups and the Cássia group presenting RI $\geq 0.8$ are showed in Fig. 2.

Of the 63 serum samples tested in group NC, $58(92.0 \%)$ presented $\mathrm{RI} \geq 0.8$ and of the 28 samples from the normal group, only one (3.6\%) presented RI $\geq 0.8$. Of the 23 sera from group OP, $9(39.1 \%)$ presented $\mathrm{RI} \geq 0.8$, two of them being from individuals with toxocariasis, five from individuals with toxoplasmosis, one from a patient with Chagas disease, and one from a patient with schistosomiasis.

In the Cássia dos Coqueiros group, 459 (24.6\%) samples presented $\mathrm{RI} \geq 0.8$ by ELISA-Tcra. Of these 459 samples, 216 (47.0\%) presented 


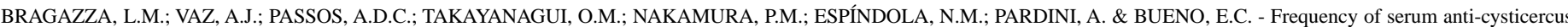
antibodies in the population of a rural Brazilian community (Cássia dos Coqueiros, SP) determined by ELISA and immunoblotting using Taenia crassiceps antigens. Rev. Inst. Med. trop. S. Paulo, 44(1):7-12, 2002

RI from 0.80 to 0.99 and $243(53.0 \%)$ RI $\geq 1.0$. The age and sex distribution of these results is presented in Fig. 3.

Immunoblotting (WB-Tcra): Fig. 4 shows the aspect of the WBTcra for serum samples. The 57 samples (100\%) from group NC processed by WB-Tcra presented the 14 and $18 \mathrm{kD}$ peptides. The serum samples from the $\mathrm{N}$ group and the 9 samples from the OP group with RI $\geq 0.8$ by the ELISA-Tcra did not react with 14 and $18 \mathrm{kD}$ peptides in the WB-Tcra.

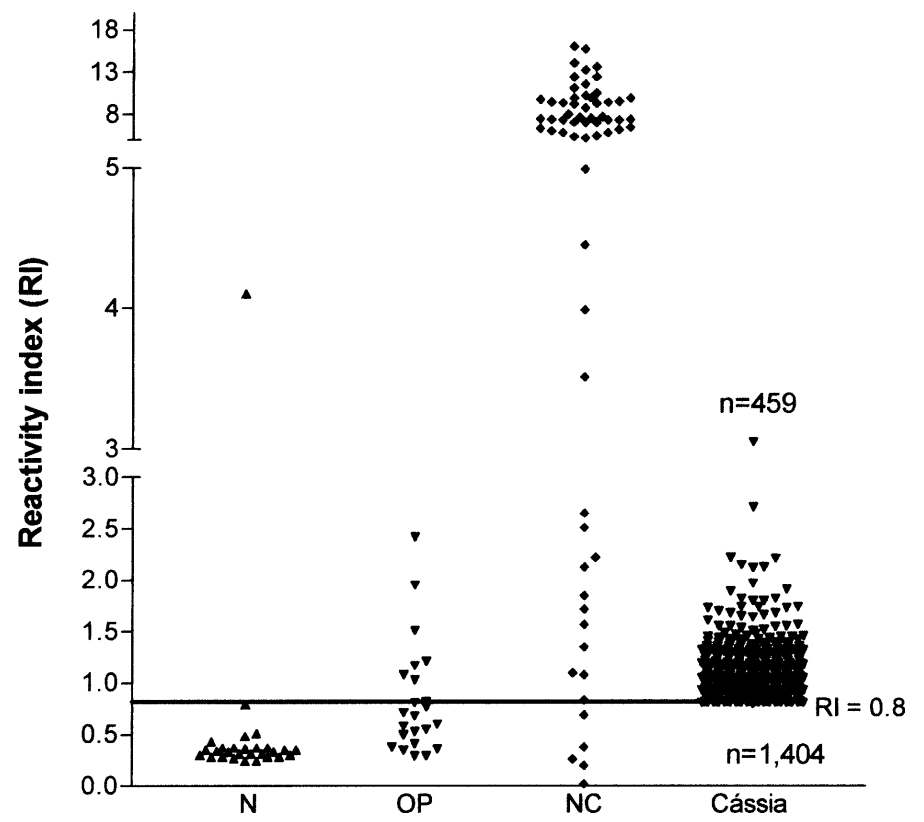

Fig. 2 - Results of the ELISA-Tcra for the groups: Normal (N), Other Pathologies (OP) and Neurocysticercosis (NC), and results with $\mathrm{RI} \geq 0.8$ for the population of Cássia dos Coqueiros (Cássia).

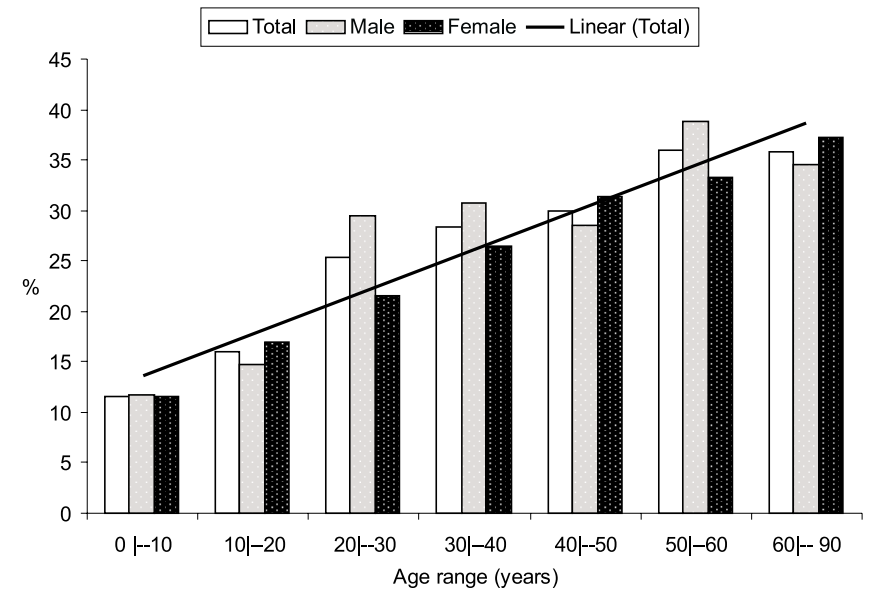

Age: $p=0.0000001$, Sex: $p=0.53$

Fig. 3 - Results of the ELISA-Tcra with a reactivity index (RI) $\geq 0.8$ for serum samples of Cássia Group in percentage by age range and sex.

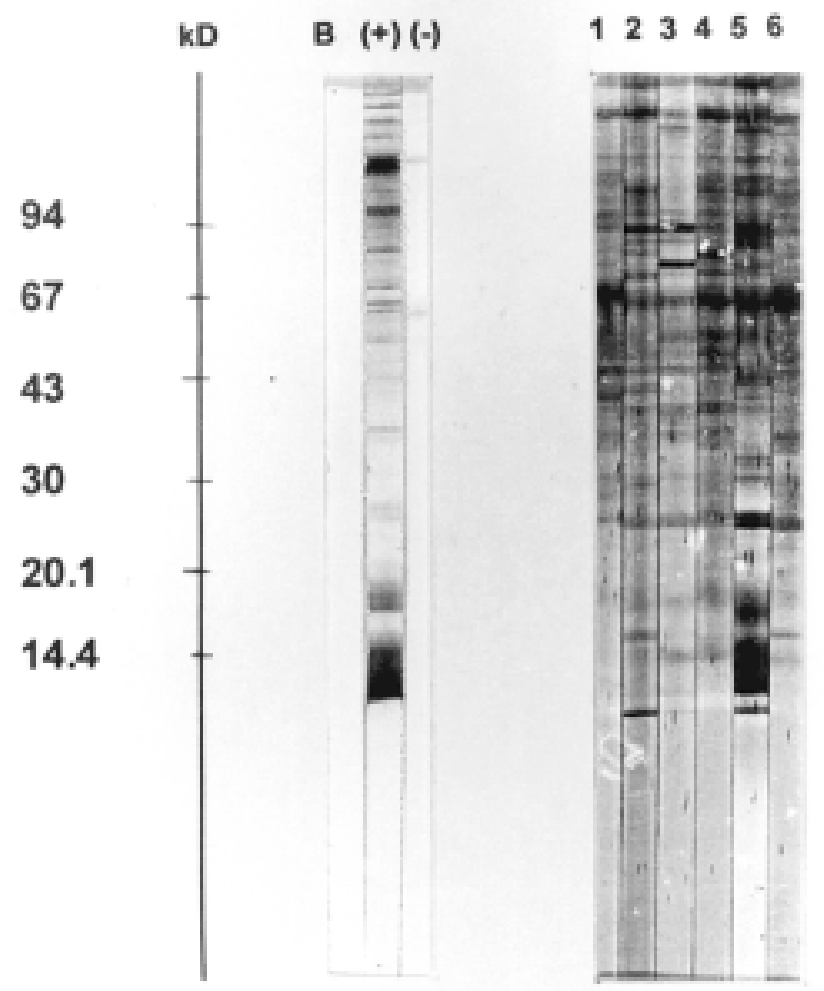

Fig. 4 - Immunoblotting using antigenic extract from vesicular fluid of T. crassiceps (SDSPAGE 7 to $20 \%)$. B = blank, (+) positive, (-) negative, 1 to $6=$ some samples from Cássia Group.

Of the 459 samples from Cássia dos Coqueiros that presented RI $\geq$ 0.8 in the ELISA-Tcra, $40(8.7 \%)$ were strongly reactive in the WBTcra. Of these 40 reactive samples, six $(15.0 \%)$ showed RI from 0.80 to 0.99 and $34(85.0 \%)$ showed RI $\geq 1.0$ in ELISA-Tcra. Table 1 presents the distribution of these 40 samples reactive in the WB-Tcra by age range and sex in relation to the total number of samples.

The frequency distribution of the 40 individuals with sera reactive in the WB-Tcra by area of residence was $1.43 \%(n=11 / 769)$ for the urban area and $2.71 \%(\mathrm{n}=29 / 1,069)$ for the rural area $(\mathrm{p}=0.06)$.

Of the 40 individuals with sera reactive in the WB-Tcra, 39 provided information about source of drinking water and presence or absence of fecal coliforms. Of these 39 individuals, $28.2 \%(n=11)$ used chlorinated water and $71.8 \%(\mathrm{n}=28)$ used untreated water. Of the 28 individuals who used untreated water, $78.6 \%(\mathrm{n}=22)$ used water from collective sources and $21.4 \%(n=6)$ used water from individual sources. Anticysticercus antibodies were detected in $1.44 \%(n=11 / 766)$ of the individuals who consumed chlorinated water, $3.37 \%(n=22 / 653)$ of the individuals who consumed untreated water from collective sources $(\mathrm{p}=$ $0.023)$ and $1.44 \%(n=6 / 418)$ of the individuals who consumed untreated water from individual sources. Of the 39 individuals positive by the WB-Tcra, $26(66.7 \%)$ used water contaminated with fecal coliforms and $13(33.3 \%)$ used uncontaminated water. Thus, $2.97 \%(n=26 / 875)$ of the individuals who used water contaminated with fecal coliforms $(\mathrm{p}=$ 


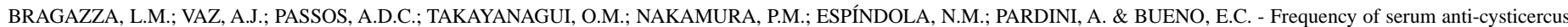
antibodies in the population of a rural Brazilian community (Cássia dos Coqueiros, SP) determined by ELISA and immunoblotting using Taenia crassiceps antigens. Rev. Inst. Med. trop. S. Paulo, 44(1):7-12, 2002.

Table 1

Distribution of samples reactive to WB-Tcra by individual age range and sex in relation to the total population studied of Cássia dos Coqueiros

\begin{tabular}{|c|c|c|c|c|c|c|}
\hline \multirow{2}{*}{$\begin{array}{l}\text { Age range } \\
\text { Years }\end{array}$} & \multirow[b]{2}{*}{$\mathrm{n} / \mathrm{N}$} & \multirow[b]{2}{*}{$\%$} & \multicolumn{2}{|c|}{ Male } & \multicolumn{2}{|c|}{ Female } \\
\hline & & & $\mathrm{n} / \mathrm{N}$ & $\%$ & $\mathrm{n} / \mathrm{N}$ & $\%$ \\
\hline $0 \mid-10$ & $04 / 214$ & $1.8 \%$ & $02 / 127$ & $1.5 \%$ & $02 / 87$ & $2.3 \%$ \\
\hline $10 \mid-20$ & $07 / 443$ & $1.6 \%$ & $05 / 209$ & $2.4 \%$ & $02 / 234$ & $0.8 \%$ \\
\hline $20 \mid-30$ & $05 / 367$ & $1.3 \%$ & $02 / 173$ & $1.1 \%$ & 03/194 & $1.5 \%$ \\
\hline $30 \mid-40$ & $04 / 274$ & $1.4 \%$ & $01 / 127$ & $0.8 \%$ & $03 / 147$ & $2.0 \%$ \\
\hline $40 \mid-50$ & $13 / 217$ & $6.0 \%$ & $05 / 112$ & $4.4 \%$ & 08/105 & $7.6 \%$ \\
\hline $50 \mid-60$ & $03 / 150$ & $2.0 \%$ & $0 / 72$ & $0 \%$ & $03 / 78$ & $3.8 \%$ \\
\hline$\geq 60$ & $04 / 173$ & $2.3 \%$ & $01 / 98$ & $1.0 \%$ & $03 / 75$ & $4.0 \%$ \\
\hline No information & $0 / 25$ & $0 \%$ & & & & \\
\hline Total & $40 / 1,863$ & $2.1 \%$ & $16 / 918$ & $1.7 \%$ & $24 / 920$ & $2.6 \%$ \\
\hline
\end{tabular}

$\mathrm{n}=$ number of WB-Tcra reactive samples. $\mathrm{N}=$ total number of samples by age range. Sex: $\mathrm{p}=0.27$; Age: (Fisher $\mathrm{p}=0.82<10$ years and $>10$ years)

$0.021)$ and $1.39 \%(n=13 / 934)$ of those who used uncontaminated water presented anti-cysticercus antibodies.

Considering the specificity of the results of the WB-Tcra, the frequency of positivity for anti-cysticercus antibodies in the population of Cássia dos Coqueiros, SP, was $2.1 \%$.

\section{DISCUSSION}

The objective of the present study was to contribute to the study of human cysticercosis using the ELISA-Tcra and WB-Tcra for the detection of anti-cysticercus antibodies in serum samples from individuals living in the municipality of Cássia dos Coqueiros, SP.

The Taenia crassiceps antigen extract was used by VAZ et al. ${ }^{32}$ and BUENO et al. ${ }^{2}$ in the ELISA and immunoblot tests for the detection of antibodies in cerebrospinal fluid and serum samples from patients with neurocysticercosis with good efficiency. The advantages of these tests are easy antigen preparation, guaranteed homogeneity of the prepared lots, lower cost, and good reproducibility.

The present results with the ELISA-Tcra showed $92.0 \%$ sensitivity and $96.4 \%$ specificity (Fig. 2), in agreement with the values reported by BUENO et al. ${ }^{2}$.

Nine $(39.1 \%)$ samples from group OP, which cross-reacted in the ELISA-Tcra, did not react when processed by WB-Tcra. Similarly, the ELISA-Tcra showed a high frequency of false-positive results in the population studied. The group of other pathologies is expected to represent the general population, especially in our country where parasitic diseases are highly prevalent, and therefore cross-reactions may occur in screening tests such as ELISA ${ }^{8}$, with the results requiring later confirmation with a more specific test such as $\mathrm{WB}^{2}$.

In a comparative study using $T$. solium antigen, DIAZ et al. ${ }^{7}$ detected sensitivity and specificity of $65 \%$ and $63 \%$ in the ELISA test and of $94 \%$ and $100 \%$ in the WB test, respectively. Despite the high specificity of the WB test commonly observed by various authors ${ }^{2,7,12,24,29,32}$, crossreactions with other parasites may occur ${ }^{18}$. The wide divergence in the sensitivity (69.0 to $87.0 \%$ ) of serologic tests observed by various authors ${ }^{6,7,20}$ reflects differences not only in the methodology employed (antigen, reagents, techniques), but also in the characteristics of the population investigated ${ }^{23}$.

The results of the ELISA-Tcra revealed a $24.6 \%$ positivity rate $(n=459)$ in the group from Cássia dos Coqueiros. The most reactive age range was that beyond 50 years (Fig. 3, p < 0.05), indicating a tendency to an increase in the prevalence of immunoreactivity with age, in agreement with data reported by AGAPEJEV ${ }^{1}$, with no sex difference.

Of the 459 samples with $\mathrm{RI} \geq 0.8$ in the ELISA-Tcra, $8.7 \%(n=40)$ were strongly reactive in the WB-Tcra, corresponding to a $2.1 \%$ frequency of reactivity for anti-cysticercus antibodies in the Cássia group. These data agree with the frequencies obtained in the few serologic surveys of cysticercosis reported in the literature, which ranged from 0.68 to $5.2 \%$ in Brazil ${ }^{30,34}$. The only important association observed between antibody frequency and the variables concerning sanitary conditions was the source of drinking water, with a higher serum reactivity being detected for consumption of water from collective sources $(p=0.023)$, a finding compatible with the high degree of contamination with fecal coliforms in these sources $(\mathrm{p}=0.021)$.

Of the 40 serum samples that reacted in the WB-Tcra, six $(15.0 \%)$ had an RI value of 0.8 to 0.99 in the ELISA-Tcra. This means that, by selecting for immunoblotting the samples with RI $\geq 0.8$ in the ELISATcra, we obtained a $91.2 \%$ rate of false-positive results. If we had selected only samples with $\mathrm{RI} \geq 1.0$ we would have had $243(13.0 \%)$ serum samples reactive to the WB-Tcra, reducing the frequency to $1.8 \%$ in the group. If we had increased the RI to 1.2 we would have had $120(6.4 \%)$ reactive samples by ELISA ( $85.0 \%$ rate of false-positive results) and 17 reactive samples by WB-Tcra, reducing the frequency of reactivity to $0.9 \%$ without a significant alteration of the specificity of the test. Thus, the selection of appropriate cut-off values should be judicious, especially when the objective of the technique employed is serologic screening, since the efficiency of the test depends on this selection. When evaluating serum samples by ELISA carried out with $T$. solium vesicular fluid antigen, LARRALDE et al. ${ }^{14}$ reported 80.0 to $95.0 \%$ sensitivity according to the cut-off established with the control group of endemic and nonendemic areas, respectively. These data support the importance of 


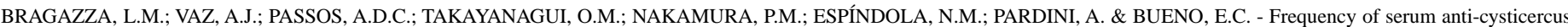
antibodies in the population of a rural Brazilian community (Cássia dos Coqueiros, SP) determined by ELISA and immunoblotting using Taenia crassiceps antigens. Rev. Inst. Med. trop. S. Paulo, 44(1):7-12, 2002.

adequate selection of the samples used as controls (patients and healthy individuals) and of the selection of the cut-off for the test.

Analysis of the present results leads us to conclude that the ELISA test carried out using the antigen of $T$. crassiceps vesicular fluid proved to be adequate for serum screening studies, but, as expected, the most specific selection occurred with the WB-Tcra. Although recommended by TSANG et al. ${ }^{29}$ for the evaluation of seroprevalence of anti-cysticercus antibodies in population groups, the immunoblot test is too costly for application to populations of developing countries.

Among the advantages of the use of ELISA are simplicity of execution, low cost, rapidity and the possibility of testing a large number of samples in each assay. The $T$. crassiceps antigen used for ELISA needs further studies, especially with respect to fractionation, but the results obtained confirm the usefulness of this working approach. Epidemiological studies will also contribute to the analysis of the general picture of cysticercosis, permitting the identification of geographic niches of the disease, with the consequent creation of satisfactory mechanisms of intervention reducing the impact of the disease on public health.

\section{RESUMO}

\section{Frequência de anticorpos séricos anti-cisticerco na população de uma comunidade rural brasileira (Cássia dos Coqueiros, SP) determinada por ELISA e imunoblot usando antígenos de Taenia crassiceps}

Considerando o impacto na saúde pública gerado pela ocorrência da cisticercose, especialmente a forma neurológica, neurocisticercose (NC), foi estudada a freqüência de positividade de anticorpos anti-cisticerco em amostras de soro de 1.863 habitantes do município de Cássia dos Coqueiros, SP, situado a $80 \mathrm{Km}$ de Ribeirão Preto, região considerada endêmica para a cisticercose. As amostras foram avaliadas pelo teste ELISA usando extrato antigênico de líquido vesicular de Taenia crassiceps (Tcra) e as amostras reagentes e inconclusivas foram analisadas pelo imunoblot. Das 459 amostras submetidas ao imunoblot, 40 foram fortemente imunorreativas para os peptídeos imuno dominantes de $18 \mathrm{e} 14 \mathrm{kD}$. Considerando o uso do teste imunoblot como confirmatório, dada sua elevada especificidade, a soroprevalência de anticorpos anti-cisticerco foi de $2,1 \%$ na população estudada.

\section{ACKNOWLEGMENTS}

This research was supported by FAPESP (grant 97/02245-6).

We are indebted to Dr. Luis dos Ramos Machado for providing the NC samples.

\section{REFERENCES}

1. AGAPEJEV, S. - Epidemiology of neurocysticercosis in Brazil. Rev. Inst. Med. trop. S. Paulo, 38: 207-216, 1996.

2. BUENO, E.C.; VAZ, A.J.; MACHADO, L.D.R.; LIVRAMENTO, J.A. \& MIELLE, S.R - Specific Taenia crassiceps and Taenia solium antigenic peptides for neurocysticercosis immunodiagnosis using serum samples. J. clin. Microbiol., 38: 146-151, 2000.

3. CAMACHO, S.D.; RUIZ, A.C.; BELTRÁN, U.M. \& WILLMS, K. - Serology as an indicator of Taenia solium tapeworm infections in a rural community in Mexico. Trans. roy. Soc. trop. Med. Hyg., 84: 563-566, 1990.
4. CHIMELLI, L.; LOVALHO, F.A. \& TAKAYANAGUI, O.M. - Contribuição da necrópsia na consolidação da notificação compulsória em Ribeirão Preto, SP. Arq. Neuropsiquiatr., 56: 577-584, 1998.

5. COKER-VANN, M.R.; SUBIANTO, D.B.; BROWN, P. et al. - ELISA antibodies to cysticerci of Taenia solium in human populations in New Guinea, Oceania, and Southeast Asia. Southeast Asian J. trop. Med. publ. Hlth., 12: 499-505, 1981

6. CORONA, T.; PASCOE, D.; GONZÁLES-BARRANCO, D. et al. - Anticysticercous antibodies in serum and cerebrospinal fluid in patients with cerebral cysticercosis. $\mathbf{J}$. Neurosurg. Psychiatr., 49: 1044-1049, 1986.

7. DIAZ, J.F.; VERASTEGUI, M.; GILMAN, R.H. et al. - Immunodiagnosis of human cysticercosis (Taenia solium): a field comparison of an antibody-enzyme-linked immunosorbent assay (ELISA), an antigen-ELISA, and an enzyme-linked immunoelectrotransfer blot (EITB) assay in Peru. The Cysticercosis Working Group in Peru (CWP). Amer. J. trop. Med. Hyg., 46: 610-615, 1992.

8. EARNEST, M.P.; RELLER, L.B.; FILLEY, C.M. \& GREK, A.J. - Neurocysticercosis in the United States: 35 cases and a review. Rev. infect. Dis., 9: 961-979, 1987.

9. FREEMAN, R.S. - Studies on the biology of Taenia crassiceps. Can. J. Zool., 40: 969 990, 1962.

10. FRITZSCHE, M.; GOTTSTEIN, B.; WIGGLESWORTH, M.C. \& ECKERT, J. Serological survey of human cysticercosis in Irianese refugee camps in Papua, New Guinea. Acta trop. (Basel), 47: 69-77, 1990

11. GARCIA, E.; ORDOÑEZ, G. \& SOTELO, J. - Antigens from Taenia crassiceps cysticerci used in complement fixation, enzyme-linked immunosorbent assay, and Western blot (immunoblot) for diagnosis of neurocysticercosis. J. clin. Microbiol., 33: 3324 3325,1995

12. GOTTSTEIN, B.; ZINI, D. \& SCHANTZ, P.M. - Species-specific immunodiagnosis of Taenia solium cysticercosis by ELISA and immunoblotting. Trop. Med. Parasit., 38: 299-303, 1987.

13. LAEMMLI, U.K. - Cleavage of structural proteins during the assembly of the head of bacteriophage T4. Nature (Lond.), 227: 680-685,1970.

14. LARRALDE, C.; LACLETTE, J.P.; OWEN, C.S. et al. - Reliable serology of Taenia solium cysticercosis with antigens from cyst vesicular fluid: ELISA and hemagglutination tests. Amer. J. trop. Med. Hyg., 35: 965-973, 1986.

15. LARRALDE, C.; SOTELO, J.; MONTOYA, R.M. et al. - Immunodiagnosis of human cysticercosis in cerebrospinal fluid. Antigens from murine Taenia crassiceps cysticerci effectively substitute those from porcine Taenia solium. Arch. Path. Lab. Med., 114: $926-928,1990$

16. MINISTÉRIO DA SAÚDE - Resolução N $\mathbf{1 9 6 / 9 6}$ sobre pesquisa envolvendo seres humanos. Brasília, Conselho Nacional de Saúde, 1996.

17. PAMMENTER, M.D.; ROSSOUW, E.J. \& DINGLE, C.E. - Serological detection of cysticercosis in two rural areas of South Africa. Trans. roy. Soc. trop. Med. Hyg., 81: 242-244, 1987.

18. PAMMENTER, M.D.; EPSTEIN, S.R. \& REES, R.T. - Cross reactions in the immunodiagnosis of schistosomiasis and cysticercosis by a cerebrospinal fluid enzyme-linked immunosorbent assay. Trans. roy. Soc. trop. Med. Hyg., 86: 51-52, 1992

19. PASSOS, A.D.C.; GOMES, U.A.; FIGUEIREDO, J.F.C. et al. - Influência da migração na prevalência de marcadores sorológicos de hepatite B em comunidade rural. 1. Análise da prevalência segundo local de nascimento. Rev. Saúde públ. (S.Paulo), 27: 30-35, 1993

20. RAMOS-KURI, M.; MONTOYA, R.M.; PADILHA, A. et al. - Immunodiagnosis of neurocysticercosis. Disappointing performance of serology (enzyme-linked immunosorbent assay) in an unbiased sample of neurological patients. Arch. Neurol. 49: 633-636, 1992. 


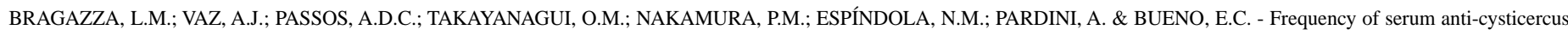
antibodies in the population of a rural Brazilian community (Cássia dos Coqueiros, SP) determined by ELISA and immunoblotting using Taenia crassiceps antigens. Rev. Inst. Med. trop. S. Paulo, 44(1):7-12, 2002.

21. SARTI-GUTIERREZ, E. \& GUTIERREZ OSPINA, I. - La taeniasis y cisticercosis en Mexico. Salud públ. Méx., 28: 556-563, 1986.

22. SARTI-GUTIERREZ, E.; SCHANTZ, P.; LARA-AGUILERA, R.; GÓMEZ DANDOY, H. \& FLISSER, A. - Taenia solium taeniasis and cysticercosis in a Mexican village. Trop. Med. Parasit., 39: 194-198, 1988.

23. SCHANTZ, P.M.; TSANG, V.C.W. \& MADDISON, S.E. - Serodiagnosis of neurocysticercosis. Rev. infect. Dis., 10: 1231-1232, 1988.

24. SCHANTZ, P.M.; SARTI, E.; PLANCARTE, A. et al. - Community based epidemiological correlations of ELISA and immunoblot assays for Taenia solium cysticercosis in 2 populations in México. Amer. J. trop. Med. Hyg., 45: 130-131, 1991.

25. SCHANTZ, P.M.; MOORE A.C.; MUÑOZ J.L. et al. - Neurocysticercosis in an orthodox Jewish community in New York City. New. Engl. J. Med., 327: 692-695, 1992.

26. SCHANTZ, P.M.; SARTI, E.; PLANCARTE, A. et al. - Community-based epidemiological investigations of cysticercosis due to Taenia solium: comparison of serological screening tests and clinical findings in two populations in Mexico. Clin. infect. Dis., 18: 879-885, 1994.

27. SCHENONE, H.; VILLARROEL, F.; ROJAS, A. \& RAMÍREZ, R. - Epidemiology of human cysticercosis in Latin America. In: FLISSER, A.; WILLMS, K.; LACLETTE, J.P. et al. Cysticercosis: present state of knowledge and perspectives. New York, Academic Press, 1982. p. 25-38.

28. TOWBIN, H.; STAEHELIN, T. \& GORDON, J. - Electrophoretic transfer of proteins from polyacrylamide gels to nitrocellulose sheets: procedure and some applications. Proc. nat. Acad. Sci., 76: 4350-4352, 1979.
29. TSANG, V.C.W.; BRAND, J.A. \& BOYER, A.E. - An enzyme-linked immunoelectrotransfer blot assay and glycoprotein antigens for diagnosing human cysticercosis (Taenia solium). J. infect. Dis., 159: 50-59, 1989.

30. VAZ, A.J.; HANASHIRO, A.S.G.; CHIEFFI, P.P. \& FERREIRA, A.W. - Freqüência de indivíduos com anticorpos séricos anti-Cysticercus cellulosae em cinco municípios do estado de São Paulo. Rev. Soc. bras. Med. trop., 23: 97-99, 1990.

31. VAZ, A.J.; MACHADO, A.B.B.; NUNES, C.M.; SILVA, M.V. \& PIAZZA, R.M.F. Utilização de líquido vesicular de Cysticercus longicollis no teste ELISA para o imunodiagnóstico da neurocisticercose humana (comunicação). Rev. Soc. bras. Med. trop., 24: 176, 1991 .

32. VAZ, A.J.; NUNES, C.M.; PIAZZA, R.M.F. et al. - Immunoblot with cerebrospinal fluid from patients with neurocysticercosis using antigen from cysticerci of Taenia solium and Taenia crassiceps. Amer. J. trop. Med. Hyg., 57: 354-357, 1997a.

33. VAZ, A.J.; NAKAMURA, P.M.; BARRETO, C.C. et al. - Immunodiagnosis of human neurocysticercosis: use of heterologous antigenic particles (Cysticercus longicollis) in indirect immunofluorescence test. Serodiag. Immunother. infect. Dis., 8: 157 $161,1997 b$.

34. VIANNA, L.G.; MACÊDO, V.; COSTA, J.M.; MELLO, P. \& SOUZA, D. - Estudo soroepidemiológico da cisticercose humana em Brasília, Distrito Federal. Rev. Soc. bras. Med. trop., 19: 149-156, 1986.

Received: 11 April 2001

Accepted: 14 November 2001 